\title{
OVERVIEW OF BITUMINOUS MIXTURES MADE WITH RECYCLED \\ CONCRETE AGGREGATES
}

A.R. Pasandin ${ }^{a,{ }^{*}}$ and I. Pérez ${ }^{a}$

${ }^{a}$ Universidade da Coruña, E. T. S. I. Caminos, Canales y Puertos, Campus de Elviña s/n, 15071. A Coruña, Spain

* Corresponding author. Tel.: +34-981167000. Fax: +34-981167170

E-mail addresses: arodriguezpa@udc.es (A.R.Pasandín),iperez@udc.es (I.Pérez)

\begin{abstract}
Recycled concrete aggregates (RCA) appear to be suitable materials to use in hot-mix asphalt (HMA) for flexible road pavements. However, the poor quality of RCA results in different engineering properties of an HMA using RCA compared to mixtures composed of natural aggregates. This paper presents a review on the properties of HMA with RCA. Varied laboratory results were obtained, likely because of the heterogeneous nature and origin of the RCA. Nevertheless, a majority of the studies report a high stripping potential of RCA mixtures. Several treatments help mitigate this problem. Additionally, select test stretches of the RCA mixture exhibited good performance. Keywords: recycled concrete aggregates; hot-mix asphalt; mechanical properties; test stretches.
\end{abstract}

\section{Introduction}

During construction, a substantial amount of natural resources are consumed, which makes the construction industry a strong candidate for reusing waste as raw materials. In particular, road construction is a unique case. The road network is large and disseminated throughout a wide geographical region. For these reasons, there is great potential to reuse waste materials in both construction and maintenance of roads. Because the road construction industry is the largest consumer of aggregates in Europe [1], using waste as recycled aggregates is a primary way to incorporate waste in the construction and maintenance process.

Several studies have investigated the incorporation of various wastes such as construction and demolition wastes, end-of-life tires, reclaimed asphalt pavement, used motor oils, plastics, and asphalt shingles into road pavement layers [2-12]. 
In particular, construction and demolition waste (C\&DW) is the most notable recyclable material within the construction industry [13]. C\&DW is defined as the debris materials resulting from the construction, renovation or demolition of structures such as commercial buildings, individual residences or civil engineering structures [14]. However, no global definition of C\&DW has been established. For example, in Germany, excavation waste is included in the definition of C\&DW [15].

Because C\&DW are generally not hazardous materials, proper source separation is necessary to remove the small amounts of hazardous waste such as asbestos and phenol [15]. As seen in Table 1, the average composition of C\&DW [14, 16-19] consists mainly of variable percentages of concrete, masonry, asphalt, wood, metal, gypsum, plastics and miscellaneous materials; the composition depends on the changing nature of construction and building materials over the time [14] and for different construction practices around the world. As shown in Table 1, C\&DW has a heterogeneous composition. Therefore, not all of the management options (i.e., reusing, recycling and energy recovery) are applicable to each of the materials that are included in this type of waste. Specifically, petrous materials (i.e., concrete and stone) can neither be reused (they have undergone demolition) or used in energy recovery (stones and concrete are not combustible materials). Therefore, petrous materials can only be recycled.

By applying existing technologies, new aggregates, which are known as recycled concrete aggregates (RCA), are obtained from these petrous materials. The use of RCA in the construction industry has increased in recent years [20]. However, additional research is required to diversify RCA applications and promote their use as a common practice.

The majority of research conducted on RCA pavement layers focuses on using RCA as a granular material [21-25] and as a cement-treated material in base and sub-base layers [26, 27]. This is mainly because in the lower layers, the specifications for the aggregates are less stringent than in the upper layers.

However, granular or cement-treated materials mixed with RCA may have problems with lixiviates. The fine fraction of the RCA can be diluted with water and cause an increase in $\mathrm{pH}$ that could be detrimental for the surrounding environment [28]. However, in hot-mix asphalt 
(HMA), leachates are avoided because the aggregates are coated with bitumen; thus, RCA are suitable for usage in HMA for flexible pavements in road construction [28]. Nevertheless, the poor quality of RCA results in different engineering properties of HMA that include RCA compared to mixtures comprised of only natural aggregates.

\section{Aims and scope}

The primary objective of this state-of-the-art study is to critically analyse the mechanical performance of HMA manufactured with partial replacement of natural aggregates by RCA. The purpose of this overview is to examine previous and current laboratory research and field experiences of such mixtures with a focus on highlighting the main aspects that must be solved or further investigated. The aim of this overview is also to examine the specifications that exist all around the world and identify if it is necessary to develop new specifications. Finally, this state-of-the-art will collect information that could be helpful when planning new investigations and generalising the sustainable use of RCA in flexible pavement road construction.

To achieve all of these objectives, first, a description of RCA is provided. Second, the paper summarizes the main properties of HMA containing RCA. Third, a section with the treatments used to improve the properties of HMA made with RCA is presented. Fourth, field experiences and specifications are analysed. Finally, the main conclusions are presented.

\section{Recycled concrete aggregates}

A simple visual inspection helps to determine the differences between RCA and natural aggregates. Figure 1 shows a typical RCA. As seen in figure 1a, a common RCA particle consists primarily of an original natural aggregate partially covered by a mortar layer. This attached mortar is more porous and less dense than the original natural aggregate [20, 29-33] and has relatively weak bonding with the original natural aggregate [34], which negatively affects the RCA properties. Moreover, the attached mortar has a variable content or thickness, age, composition, porosity and texture. Nevertheless, in this regard, most authors only highlight the influence of the attached mortar content on the properties of the RCA without taking into 
account all of the other properties previously discussed. Only a few studies [36] indicate that small cracks appear during the crushing process that degrade the properties of RCA

Figure $1 \mathrm{~b}$ shows that besides these common particles, the RCA also includes other materials: mortar fragments, stones and aggregates without mortar, ceramics, asphalt and other impurities such as gypsum, wood, glass, paper or metals; these impurities should be removed to improve the RCA heterogeneity [29-31, 35].

For all of these reasons, RCA are generally lower quality than natural aggregates $[20,36]$ and will affect the performance of hot-mix asphalt.

\section{Properties of HMA using RCA}

\subsection{Asphalt content}

The majority of studies have stated that HMA using RCA have higher optimum asphalt contents (OAC) than conventional mixtures $[28,30-33,36-43]$ mainly because of the high porosity of the attached mortar $[28,43]$. Several typical findings, shown in figure 2, illustrate the relationship between the percentage of RCA and bitumen consumption. As seen in figure 2, the bitumen content increases with a higher RCA content. The OAC obtained by the different studies varies greatly. The different materials used (natural aggregates, RCA and fillers) could influence the asphalt consumption. Additionally, the mix design and use of treatments could affect the asphalt content. However, the national specifications of each country are the primary reason for different OAC for identical percentages of RCA.

Figure 2 also indicates that the bitumen consumption is greater when the RCA is added in the fine fraction [42] because of its greater mortar content [20] and larger specific surface area [38]. For economic reasons, Bushal et al. [41] proposed that RCA should be added to the coarse fraction to avoid high OAC.

The majority of studies report the OAC; however, few studies investigate the effective binder content (Pbe) and bitumen absorption (Pba). Select studies [29, 43-45] stated that the effective binder content of HMA using RCA was lower than conventional mixtures. A higher bitumen absorption by the RCA leads to less binder available to coat the aggregates [29]. This property appears to be primarily reason that the attached mortar on the RCA surface is more absorptive. 
Thus, higher percentages of RCA increase the bitumen absorption [41]. In addition, Bushal et al. [41] indicated that the Pba linearly increases with the percentage of RCA in the mixture. As shown in figure 3, if linear regression lines are drawn for the results obtained by other authors, the fits are not always as good as those obtained by Bushal et al. [41], but they are satisfactory (in all cases the $\mathrm{R}^{2}>0.9$ ).

Finally, Pérez et al. [33] indicated that coating the particles present in RCA was difficult during the mixing process, particularly for siliceous particles and quartzite because of the chemical composition of these particles and the bitumen absorbed by the mortar. Additionally, the rough texture of RCA could introduce additional difficulties in the coating process. Thus, in addition to the high OAC content of HMA using RCA, some particles in the RCA are difficult to coat.

\subsection{Volumetric properties}

HMA using RCA have higher air-voids contents (Va) than conventional mixtures [29-33, 37-38, 42, 46]; the Va could exceed 30\% for RCA [35]. Several authors stated that, generally, the percentage of air voids grow as the RCA percentage grows [29-33, 35, 42, 46]. Several authors attribute this variation in the air voids content to the high porosity of the attached mortar. This high porosity is primarily responsible for the bitumen absorption of the RCA and, thus, the thinner bitumen film thickness; the thin film hinders the aggregate interlock after compaction [30-33]. However, as seen in figure 4a, this trend was not seen in all studies likely because of the design method used (for example some mix design methods indicate that a target air void content or a minimum film thickness must be reached) so the bitumen content increases as the percentage of RCA increases.

The RCA content also affects the voids in the mineral aggregate content (VMA) and the voids filled with asphalt content (VFA). Several authors indicate that as the percentage of the RCA increases, the VMA and VFA decrease $[41,45]$. However, as seen in figure $4 \mathrm{~b}$ and figure $4 \mathrm{c}$, several authors reported a contrary trend, likely because the design method used increased the bitumen content. Several countries have specifications for the VFA. Therefore, some HMA made with RCA fail to reach the minimum VFA value established by national specifications [28]. 


\subsection{Marshall flow and Marshall stability}

As illustrated in figure 5, several authors stated that using RCA increases the Marshall stability of the mixture $[28,32,47]$; however, other authors [36, 42] obtained the opposite result. Additionally, other studies indicate that the Marshall stability of mixtures with RCA is close to that of conventional mixtures $[44,48]$. This lack of consensus could result from the fraction of RCA used. In this regard, Arabani and Azarhoosh [49] and Arabani et al. [50] indicated that using RCA as fines and filler increased the Marshall stability, whereas Zhu et al. [51] indicated that employing RCA in both the coarse and fine fractions resulted in the lowest Marshall stability. Additionally, using treated RCA could affect the Marshall stability trends. Therefore, Zhu et al. [51] stated that a noticeable increase in the Marshall stability was obtained by pretreating the coarse RCA with a patented liquid-silicone resin. However, Lee et al. [36] stated that mixtures comprised of RCA coated with a slag cement paste showed lower Marshall stability. Additionally, Wong et al. [28] reported a decrease in the Marshall stability when using heat-treated RCA. However, Pasandín and Pérez [44] reported that curing a mixture of RCA for 4 hours in an oven did not significantly affect the Marshall stability. Despite the variety of reported results, a common key conclusion can be extracted from the literature review: the bituminous mixtures using RCA generally meet the national Marshall stability and flow specifications $[28,30-33,36,48,51-53]$. Therefore, these mixtures will have a sufficient capacity to withstand traffic loads.

However, it is necessary to clarify two issues. On the one hand, some authors indicate that a certain value of natural aggregate replacement by RCA only complies with requirements $[35$, 42]. This limit, which varies between $30 \%$ and $50 \%$ RCA, depends on the following factors: the nature of the virgin aggregate, the nature and origin of the RCA, the treatment used to improve the RCA properties and the type of mineral filler used. Therefore, with a proper selection of materials used to combine with the RCA (natural aggregate, mineral filler, and bitumen), the requirements for the Marshall stability should be met. On the other hand, several authors [3031] indicated that the Marshall criteria are met only for medium and low traffic. 
Additionally, several authors $[29,43,46,49]$ indicated that during the mixing and compaction process, the HMA using RCA suffers from changes in grain size distribution primarily because of the weakness of the attached mortar on the RCA surface. Cho et al. [39] stated that using the Marshall mix-design method is insufficient in the manufacture of mixtures involving RCA. The primary reason provided by Cho et al. [39] is that the loading during Marshall compaction could break RCA course particles and, therefore, potentially underestimate the engineering properties of the HMA using RCA.

\subsection{Moisture damage resistance}

As seen in table 2, various investigations indicate that the moisture damage resistance of bituminous mixtures with RCA varies. Thus, moisture damage resistance is a key aspect in the analysis of HMA using RCA and must be carefully studied to guarantee satisfactory durability and performance of such mixtures. The performance depends, among other factors, on the rate of replacement of the natural aggregate by RCA and the nature of both the RCA and natural aggregate. Additionally, the mineral filler has an important role in the success of the mixture. The nature of the RCA is affected by whether the material originates from structures formed exclusively by concrete (e.g., concrete pavements, bridge abutments, etc.) or from buildings, residences, or apartments. Likewise, the composition of the original aggregate (crushed or rounded, mineralogical composition, and texture) also influences the nature of the RCA. As seen in table 2, several studies concluded that mixtures using RCA generally meet the national specifications for water resistance $[38-40,48,51-52,54]$. Many of these studies qualify this finding by stating that the resistance to the action of water decreases with an increasing percentage of RCA [40, 48, 51]; therefore, for percentages of RCA over $75 \%$, the specifications are not met [45]. However, as seen in table 2, other studies indicated contrary results in which the water resistance results are far above the minimum required values [29-33]. 


\subsection{Stiffness}

Several studies stated that employing RCA in hot-mix asphalt resulted in lower Marshall stiffnesses [35], lower resilient moduli [29, 45] or lower dynamic moduli [40, 45] than conventional mixtures. This lower stiffness is most likely because of the lower resistance of the attached mortar [29, 46, 49]. Nevertheless, other studies obtained the opposite result; mixtures comprised of RCA displayed higher resilient moduli [28, 38, 47], higher dynamic moduli of elasticity [30-31] or higher bending stiffness moduli [51]. Moreover, other authors specify that the fraction of RCA affects the results. Chen et al. [54] concluded that using RCA as a filler does not influence the resilient modulus of the mixtures. At high temperatures, the binder is primarily responsible for the stiffness of the mixtures, whereas at low temperatures, the mineral skeleton is primarily responsible [54]. As shown in figure 6, Arabani and Azarhoosh [49] and Arabani et al. [50] showed that using RCA as the fine fraction resulted in mixtures with higher resilient moduli, whereas using RCA as the coarse fraction reduced the resilient modulus. The angularity of the RCA allows mixtures with RCA in the fine fraction to display a higher stiffness, whereas the weakness of the attached mortar ensures mixtures with RCA in the coarse fraction display a lower stiffness $[49,50]$.

Thus, the variability in the results may be whether the authors employ the RCA in the coarse or fine fraction. However, differences between the various RCAs used by the authors must be considered. Moreover, when determining the stiffness of a bituminous mixture, several factors influence the results including the percentage of RCA, the temperature during the test, the binder content, the particle size distribution of the mixture and the degree of compaction. However, the majority of authors indicated that the stiffness is within the range of national specifications.

\subsection{Resistance to permanent deformation}

The literature review on permanent deformation of hot-mix asphalt involving RCA displayed varied conclusions. In some cases, these mixtures exhibited a similar [29] or better [30-33] performance compared to natural aggregates. However, several authors indicated that despite meeting the specifications, an increase in the RCA percentage leads to a decrease in the 
resistance to permanent deformation $[40,45]$. These studies showed that this reduced resistance to rutting could be explained by the increase in the asphalt content in the mixture as the RCA percentage grows [40]. This increase in asphalt content is absorbed by the aggregate and is not included in the effective bitumen content [40]. However, because of the high test temperatures, the expansion of the asphalt could lead to an increase in the effective binder content, which adversely affects the rutting performance of the mixture [40].

Other authors stated that the improvement or worsening of the resistance to permanent deformations depends not only on the use of RCA but also on the fraction of the natural aggregate that is replaced by RCA. Zhu et al. [51] found that mixtures with RCA in both fractions (coarse and fine) displayed the highest resistance to permanent deformation. Moreover, Shen and Du [37-38] also showed that using RCA in both or only in the coarse fraction displayed a better resistance to the permanent deformation than mixtures made with natural aggregates, whereas mixtures with RCA in the fine fraction displayed a poorer resistance to permanent deformation. Gul [46] stated that using RCA in the coarse fraction leads to better rutting resistance performance, whereas using RCA in the fine fraction reduces the resistance to permanent deformation. Wong et al. [28] also supported Shen and Du [37-38] by showing that using RCA in the coarse fraction improved the performance of the mixtures. The internal friction resulting from the heavily crushed faces of the coarse RCA and the high bitumen absorption of RCA are primarily responsible for this performance [37-38]. However, Cho et al. [39] showed that using RCA in both the coarse and the fine fractions lead to mixtures with the worst performance against permanent deformation (compared to those with RCA in the coarse fraction or RCA in the fine fraction). In addition, Arabani and Azarhoosh [49] indicated that the weakness of the attached mortar is primarily responsible for the degraded permanent deformation performance of mixtures with RCA in the coarse fraction. Only two studies analysed the effect of using RCA as mineral filler. Unlike Chen et al. [54] that showed an improved resistance to the permanent deformation when using RCA as filler, Wong et al. [28] reported that the using RCA as filler did not affect the resistance to permanent deformation. 
Despite this variability in results, the majority of the authors stated that asphalt mixtures with RCA meet the national specifications relating to the resistance to permanent deformation.

\subsection{Fatigue life}

Fatigue is one of the less studied properties of bituminous mixtures with RCA. Perez et al. [3031] used the results of a three-points bending fatigue test (according to the Spanish NLT-350 standard) to conclude that bituminous mixtures manufactured with RCA behave similarly to conventional mixtures. Using the results of fatigue tests from four points at $20^{\circ} \mathrm{C}$ (AASHTO T-321), Chen et al. [54] concluded that bituminous mixtures in which mineral filler from RCA was used had a higher fatigue life. Nehad et al. [55] used the indirect tensile fatigue test at $5^{\circ} \mathrm{C}$ and $40^{\circ} \mathrm{C}$ to analyse the fatigue life of mixtures containing RCA. They found that replacing the native aggregate by up to $100 \%$ of RCA improved the fatigue life of the bituminous mixtures.

\subsection{Low temperature performance}

This type of behaviour has been analysed in only a few studies. Chen et al. [54] conducted flexural dynamic fatigue tests at $-10^{\circ} \mathrm{C}$ and concluded that using recycled mineral filler can slightly degrade the resistance of hot mix asphalt against low temperature cracking. Therefore, employing this type of mineral filler is more appropriate in warm regions. Wu et al. [48] and Zhu et al. [51] studied the low temperature performance of mixtures containing RCA in a threepoint bending test at $-10^{\circ} \mathrm{C}$. Both studies concluded that using RCA can decrease the low temperature performance of HMA. Wen and Bushal [40] also analysed the thermal cracking by monitoring the tensile strength of the mixtures at $-10^{\circ} \mathrm{C}$. They concluded that the crushing of the RCA and the increased asphalt content are primarily responsible for the suboptimal lowtemperature performance of HMA containing RCA. All studies agree that the addition of RCA worsens the performance of HMA against thermal cracking at low temperatures.

\section{Traffic category}

It is important to note that most authors do not indicate the traffic category for which the mixtures were designed. Nevertheless, the limited available information suggests that HMA made with partial replacement of natural aggregate by RCA were mainly studied for low or medium traffic volumes [27-30, 32, 42, 51]. Only Pasandín and Pérez [44, 56] analysed the 
feasibility of using such mixtures in the highest traffic categories by applying treatments to the RCA as described in the next section.

\section{Treatments applied to the RCA}

As summarised in table 3, several studies have analysed the use of treatments to improve the performance of HMA with RCA. Wong et al. [28] calcined RCA obtaining lime from the calcite contained in the RCA. The filler obtained from the treated RCA produced lime, which is commonly used to improve the stripping performance of bituminous mixtures. Wong et al. [28] found that this treatment improved the resistance to permanent deformation.

Lee et al. [36] precoated the RCA with a slag cement paste, which reinforced the RCA that was weakened by tiny fissures caused by the crushing process. The coated RCA had an optimum thickness of $0.25 \mathrm{~mm}$ of slag cement paste, which produces a lower coefficient of the Los Angeles Abrasion Test, greater stiffness and lower rutting potential.

Zhu et al. [51] used RCA from demolition debris of buildings affected by the Wenchuan Earthquake (China) to manufacture HMA. Because the RCA had $28.46 \%$ ceramics and bricks, a high absorption and poor resistance RCA was expected. Therefore, Zhu et al. [51] coated the RCA with a patented liquid silicone resin. The analysis of the physical properties of the aggregates produced by Zhu et al. [51] concluded that this treatment improved both the absorption of the RCA and its resistance to fragmentation. Thus, the treatment improved the moisture damage resistance of the HMA.

Pasandín and Perez $[44,56]$ tested two treatments. The first treatment consisted of heating the loose mixture in an oven for four hours at the mixing temperature before compaction. The second treatment consisted of coating the RCA with $5 \%$ of bituminous emulsion prior to manufacturing the HMA. Both treatments produced mixtures with improved moisture damage resistance.

Although the HMA with pretreated RCAs meet the national specifications, various questions must be clarified. On the one hand, the feasibility of applying such treatments at the mixing plant must be analysed. On the other hand, the cost of the treatments, both from an economical and environmental point of view, must be analysed. However, the treatments described in this 
section are still being tested in the laboratory, so there is still a long time before it is possible to use them in the field.

\section{Specifications and applications of HMA using RCA}

Information about RCA has been limited to hot mix asphalts produced with a particular type of RCA from C\&DW. This particular RCA is the recycled aggregate obtained from crushing the waste of demolition of pavements or other structures that consist exclusively of concrete (e.g., viaduct piles). This particular type of RCA is commonly called Crushed Concrete Aggregate (CCA).

According to a study conducted by the Federal Highway Administration (FHWA) [57] in the United States of America, the use of CCA in HMA is not widely accepted. Nevertheless, 8 states report their use in technical regulations: Florida, Illinois, Louisiana, Michigan, Minnesota, Mississippi, Virginia and Utah. Even in these states, CCA is not widely used in bituminous mixtures.

Additional technical information was obtained from Michigan [58]. The specifications for conventional mixtures in Michigan permit the use of CCA in hot mix asphalt; however, CCA is only used to a limited extent in Western Michigan [57]. Michigan regulations cover the use of CCA in the coarse fraction of HMA; CCA must meet the specifications for natural aggregates, and bituminous mixtures produced with CCA must comply with the standards of conventional mixtures [58].

In Illinois, a test stretch was built between 1986 and 1987. The test stretch was constructed using three different sections where CCA was used as an aggregate in the bituminous binder layer in different percentages [59]: 100\% virgin aggregate, 50\% CCA and 100\% CCA. Bituminous mixtures with CCA displayed an equal or superior performance to that of virgin aggregate [59].

In Hempstead, New York, two test stretches were built; the first stretch was constructed in 1981 (Abbey Lane), and the second stretch was built in 1983 (Blacksmith Lane) [60]. In each stretch, two test sections used CCA in HMA for the base course layer. One section used 100\% CCA in the bituminous base course and was compared to a second section that used $100 \%$ natural 
aggregates in the bituminous base course (control mixture). Marshall tests were conducted, and the study concluded that the mixture with $100 \%$ CCA had a Marshall stability $60 \%$ higher than the control mixture. In regard to the optimum asphalt content (OAC), the control mixture has an OAC of $5.0 \%$, whereas the mixture involving CCA has a higher OAC of $5.5 \%$ in the first stretch and 5.7\% in the second stretch. Moreover, the mixture involving CCA was $16 \%$ and $11.5 \%$ less dense than the control mixture for the first and second stretch, respectively. Although the $\mathrm{OAC}$ was higher for mixtures involving CCA because the CCA was $16 \%$ or $11.5 \%$ less dense than the control mixture, Petrarca and Galdiero [60] concluded that these mixtures displayed substantial economic potential because the same pavement thickness could use $16 \%$ or $11.5 \%$ fewer tonnes of HMA.

However, the above mentioned study by the Federal Highway Administration [57] stated that given the increased binder demand of CCA (as a result of its high absorption [57, 61]), its use in bituminous mixtures does not have a promising future.

Although there is an increase in costs resulting from the increased consumption of binder, the reduction in environmental costs must also be considered (i.e., reduced consumption of raw materials, lower volume of C\&DW in landfills, etc.). As indicated by Petrarch and Galdiero [60], the lower density of HMA using CCA results in a lower mass of HMA required for constructing the same thickness as a conventional mixture.

\section{Conclusions and final remarks}

Several conclusions and remarks can be obtained from the analysis of the literature review:

- Recycled concrete aggregates from construction and demolition debris have a high potential for use in the low-volume road construction industry and support sustainable growth. The use of these aggregates in hot-mix asphalts for flexible pavements in road construction could be a way to avoid lixiviates that affect the surrounding environment.

- Nevertheless, RCA have attached mortar on their surface. This porous attached mortar is primarily responsible for RCA being of lower quality than natural aggregates. 
- Despite the varied conclusions obtained by different studies, the lower resistance to fragmentation and higher bitumen absorption of the attached mortar produce mixtures with higher stripping potential.

- Several authors demonstrated that the lower water resistance of mixtures involving RCA could be successfully solved by employing different treatments such as coating the RCA with different sealants (bitumen emulsion or liquid silicone resin), calcinating the RCA or heating the mixture in an oven prior to compaction. Nevertheless, these treatments must be further analysed to determine their economic and environmental costs and feasibility of implementation at the mixing plant.

- The test stretches that were constructed confirm that using RCA as an aggregate in HMA produces mixtures that could satisfy the requirements for conventional HMA.

- However, two key points need to be investigated further to generalise the use of HMA using RCA: the costs of manufacturing mixtures with RCA and the lack of specifications.

- Several questions arise during the analysis of the manufacturing costs of RCA mixtures. On the one hand, mixtures with RCA consume higher amounts of bitumen than conventional mixtures. On the other hand, their density is lower, which means a lower mass of mixture is required. Additionally, the environmental benefits must be considered as a cost.

- Several aspects must be considered regarding the lack of specifications for the use of RCA as aggregates in HMA. On the one hand, most studies use a Marshall-mix design method that could lead to an underestimate in the HMA properties because of the breakdown of RCA particles during compaction. On the other hand, most studies use the national requirements for conventional mixtures. For these reasons and the success of the test stretches, new specifications are required to account for the use of RCA. The specification must clearly identify the type of road and heavy traffic categories appropriate for using RCA in HMA. 


\section{Acknowledgements}

The authors wish to acknowledge the Spanish Ministry of Education and Science for sponsoring

this research through the Project BIA2010-17751.

\section{References}

[1]. Symonds A., Cowi, PRC Bouwcentrum. "Construction and Demolition Waste Management Practices, and Their Economic Impacts". Report to DGXI European Commission. 1999.

[2]. Ciesielski S.K. "The use of Recyclable Waste Materials in Hot Mix Asphalt Concrete Highways Pavements". Proceedings of the 3rd Materials Engineering Conference, San Diego, USA, 1994; p. 327-335.

[3]. NCHRP. National Cooperative Highway Research Program "Recycling and Use Of Waste Materials and By-Products in Highway Construction". Synthesis of Highway Practice 199. Tranportation Research Board, 1994.

[4]. NAPA. National Asphalt Pavement Association. "Uses of Waste Asphalt Shingles in HMA. State-of-the-Practice". Special Report 179, 1997.

[5]. Modarres A., Hamideza, H. "Developing laboratory fatigue and resilient modulus models for modified asphalt mixes with waste plastic bottles (PET)". Constr Build Mater 2014; $68 ; 259-267$.

[6]. FHWA. Federal Highway Administration. "Transportation Applications of Recycled Concrete Aggregate", 2004.

[7]. Hinislioğlu S., Ağar E. "Use of waste high density polyethylene as bitumen modifier in asphalt concrete mix". Materials letters 2004; 58 (3); 267-271.

[8]. Taha R., Al-Rawas A., Al-Jabri, K., Al-Harty A., Hassan H., Al-Oraimi S. "An overwiew of waste materials recycling in the Sultanate of Oman". Resour Conserv Recy 2004; 41 (4); 293-306.

[9]. Akbulut H., Gürer C. "Use of aggregates produced from marble quarry waste in asphalt pavements". Build environ 2007; 42; 1921-1930.

[10]. Huang Y., Bird R.N., Heidrich O. "A review of the use of recycled solid waste materials in asphalt pavements". Resour Conserv Recy 2007; 52 (1); 58-73.

[11]. Huang B., Dong Q., Burdette E.G. (2009). "Laboratory evaluation of incorporating waste ceramic materials into Portland cement and asphaltic concrete". Constr Build Mater 2009; 23 (12); 3451-3456.

[12]. Rubio M.C., Moreno F., Belmonte A., Menéndez A. "Reuse of waste material from decorative Quartz solid surfacing in the manufacture of hot bituminous mixes". Constr Build Mater 2010; 24 (4); 610-618.

[13]. FEHRL. Forum of European National Highway Research Laboratories. "Guide on techniques for recycling in pavement structures". SAMARIS (Sustainable and Advanced MAterials for Road InfraStructure). Competitive and Sustainable Growth (GROWTH) Programme, 2006.

[14]. Huang W.L, Lin D.H, Chang N.B and Lin K.S. "Recycling of construction and demolition waste via mechanical sorting process". Resour Conserv Recy 2002; 37: 23 - 37.

[15]. COWAN (Construction and Waste Management in Sri Lanka). "Construction and demolition waste management in Germany". Study. 2006.

[16]. European Commission (DG ENV). "Service Contract on Management of Construction and Demolition Waste - SR1". Final Report Task 2. February 2011.

[17]. The City of Ottawa. "IC\&I Waste Characterization Report. IC\&I 3Rs Strategy Project". Kelleher Environmental. Jacques Withford. Genivar. 2007.

[18]. Adams L.S., Kuehl S, and Leary M. "California 2008 Statewide Waste Characterization Study”. Cascadia Consulting Group. Contractor's Report. 2009. 
[19]. Ding Tao, Xiao Jianzhuang. "Estimation of building-related construction and demolition waste in Shanghai". Wast Manag 2014 (in press).

[20]. Sánchez de Juan Marta, Alaejos Gutiérrez Pilar. "Study on the influence of attached mortar content on the properties of recycled concrete aggregate". Constr Build Mater 2009; 23: 872 - 877.

[21]. Bennert T., Papp Jr W.J., Maher A., Gucunski N. "Utilization of Construction and Demolition Debris Under Traffic-Type Loading in Base and Subbase Applications", Transport Res Rec 2000; 1714; 33-39.

[22]. Arm M. "Self-cementing properties of crushed demolished concrete in unbound layers: results from triaxial tests and field tests" Waste Manage 2001; 21; 235-239.

[23]. Poon Chi Sun, Chan Dixon. "Feasible use of recycled concrete aggregates and crushed clay brick as unbound road sub-base" Constr Build Mater 2006; 20; 578-585.

[24]. Vegas I., Ibáñez J.A., Lisbona A., Sáez de Cortazar A., Frías M. "Pre-normative research on the use of mixed recycled aggregates in unbound road sections". Constr Build Mater 2011; 25: 2674-2682.

[25]. Jiménez J.R., Agrela F., Ayuso J., López M. “A comparative study of recycled aggregates from concrete and mixed debris as material for unbound road sub-base". Mater Construcc 2011; 61 (302); 289-302.

[26]. Yeo R.E.Y., Sharp K.G. "Recycled Crushed Concrete Stabilize with Cementitious Binder, in Investigation into the use of Recycled Crushed Concrete for Road Base Use". Report prepared by VicRoads et Al. for EcoRecycle Victoria, Australia, 1997.

[27]. Rakshvir S., Barai S.V. "Studies on Recycled aggregates-bases concrete". Waste Manage Res 2006; 24 (3); 225-233.

[28]. Wong Y.D., Sun D.D., Lai D. "Value-added utilisation of recycled concrete in hot-mix asphalt". Waste Manage 2007; 27: 294 - 301.

[29]. Paranavithana Sumeda, Mohajerani Abbas. "Effects of recycled concrete aggregates on properties of asphalt concrete" Resour Conserv Recy 2006; 48: 1 - 12.

[30]. Pérez I., Toledano M., Gallego J., Taibo J. "Mechanical properties of hot mix asphalt made with recycled aggregates from reclaimed construction and demolition debris". Mater Construcc 2007; 57 (285): 17 - 29.

[31]. Pérez I., Gallego J., Toledano M., Taibo, J. “Asphalt mixtures with construction and demolition debris". Proceedings of the Institution of Civil Engineers. Transport 2010; 163: $165-174$.

[32]. Pérez I., Pasandín A.R, Medina L. "Hot mix asphalt using C\&D waste as coarse aggregates". Mater Design 2012; 36: 840-846.

[33]. Pérez I., Pasandín A.R and Gallego J. "Stripping in hot mix asphalt produced by aggregates from construction and demolition waste". Waste Manage Res 2012; 30 (1): 3 11.

[34]. Tam Vivian W.Y., Tam C.M., Le K.N. "Removal of cement mortar remains from recycled concrete aggregate using pre-soaking approaches". Resour Conserv Recy 2007; 50: 82 - 101.

[35]. Cupo-Pagano M., D’Andrea A., Giavarini C., Marro C. "Use of building demolition waste for asphalt mixes: first results". Energy, environment and technological innovation. Proceedings of III International Congress; 1994; 203 - 208.

[36]. Lee Cheng-Hsiao, Du Jia-Chong, Shen Der-Hsien. "Evaluation of pre-coated recycled concrete aggregate for hot mix asphalt". Constr Build Mater 2012; 28: 66 - 71.

[37]. Shen D., Du J. "Evaluation of building materials recycling on HMA permanent deformation". Constr Build Mater 2004; 18: 391 - 397.

[38]. Shen D., Du J. "Application of Gray Rational Analysis to Evaluate HMA with Reclaimed Building Materials". J Mater Civil Eng 2005; 17: 400 - 406.

[39]. Cho Yoon-Ho, Hun Taeyoung, Kim In Tai, Choi Nyoung Rak. "The Application of Recycled Concrete Aggregate (RCA) for Hot Mix Asphalt (HMA) base Layer Aggregate". KSCE J Civ Eng 2011; 15 (3); 473-478. 
[40]. Wen Haifang, Bhusal Sushanta. "Evaluate Recycled Concrete as Hot Mix Asphalt Aggregate". Transportation Northwest (TRANSNOW). University of Washington, 2011.

[41]. Bushal Sushanta, Li Xiaojun, Wen Haifang. "Evaluation of Effects of Recycled Concrete Aggregate on Volumetrics of Hot-Mix Asphalt". Transport Res Rec 2011; 2205 (3); 3639.

[42]. Rafi Muhammad Masood, Qadir Adnan, Siddiqui Salman Hameed. "Experimental testing of hot mix asphalt mixture made of recycled aggregates". Waste Manag Res 2011; 29 (12); 1316-1326.

[43]. Muniz de Farias M., Quiñones Sinisterra F., Gómez Jiménez A.M., Ribeiro e Souza, M.V., Farias Falcão P.R. "Influence of Asphalt Rubber on the Crushing of Recycled Aggregates Used in Dense HMA". Proceedings of Asphalt Rubber. Munich, 2012.

[44]. Pasandín A.R., Pérez I. "Laboratory evaluation of hot-mix asphalt containing construction and demolition waste ". Constr Build Mater 2013; 43: 497-505.

[45]. Mills-Beale J., You Z. "The mechanical properties of asphalt mixtures with recycled concrete aggregates". Constr Build Mater 2010; 24: 340 - 345.

[46]. Gul Waqar Ahmed. Effect of Recycled cement concrete content on rutting behaviour of asphalt concrete. Doctoral Thesis. Middle East Technical University. Ankara; 2008.

[47]. Zulkati Anggraini, Wong Yiik Diew, Sun Darren Delai. "Mechanistic Performance of Asphalt-Concrete Mixture Incorporating Coarse Recycled Concrete Aggregate". J Mater Civ Eng 2013; 25; 1299-1305.

[48]. Wu Shaopeng, Zhong Jinjun, Zhu Jiqing, Wang Dongming. "Influence of demolition waste used as recycled aggregate on performance of asphalt mixture". Road Mater Pavement 2013; 14 (3); 679-688.

[49]. Arabani M, Azarhoosh A.R. "The effect of recycled concrete aggregate and steel slag on the dynamic properties of asphalt mixtures". Constr Build Mater 2012; 35; 1-7.

[50]. Arabani M, Nejad F Moghadas, Azarhoosh A.R. "Laboratory evaluation of recycled waste concrete into asphalt mixtures" Int J Pavement Eng 2012; 14 (6); 531-539.

[51]. Zhu J.; Wu S.; Zhong J.; Wang D. "Investigation of asphalt mixture containing demolition waste obtained from earthquake-damaged buildings". Constr Build Mater 2012; 29: 466475.

[52]. Aljassar A.H., Al-Fadala K.B. "Recycling building demolition waste in hot-mix asphalt concrete: a case study in Kuwait". J Mater Cycles Waste 2005; 7: 112 - 115.

[53]. Chen Meng Jia, Wong Yiik Diew. "Porous asphalt mixture with $100 \%$ recycled concrete aggregate". Road Mater Pavement 2013; 14 (4); 921-932.

[54]. Chen Meizhu, Lin Juntao, Wu Shaopeng. "Potential of recycled fine aggregates powder as filler in asphalt mixture". Constr Build Mater 2011; 25: 3909 - 3914.

[55]. Nehad Fereidoon Moghadas, Azarhoosh Ali Reza, Hamedi Gholam Hossein. "The effects of using recycled concrete on fatigue behavior of hot mix asphalt". J Civ Eng Manag 2013; 19 (1); 561-568.

[56]. Pasandín A.R., Pérez I. "Mechanical properties of hot-mix asphalt made with recycled concrete aggregates coated with bitumen emulsion". Constr Build Mater 2014; 55 ; 350358.

[57]. FHWA. Federal Highway Administration. "Transportation Applications of Recycled Concrete Aggregate". FHWA State of the Practice National Review. September 2004

[58]. MDOT. Michigan Department of Transportation. "Using Recycled Concrete in MDOT's Transportation Infraestructure-Manual of Practice". Final Report, 2011.

[59]. Schutzbach A.M. (1992). "Case Study of a Full-Depth Asphalt Concrete Inlay". Transp Res Rec 1992; 1337; 42-50.

[60]. Petrarca R.W., Galdiero V.A. "Summary of Testing of Recycled Crushed Concrete" Transp Res Rec 1984; 989; 19-26.

[61]. Anonymus. "Concrete Runway Recycled As Asphalt Runway". Highway \& Heavy Construction 1984; 127 (9); 44-46. 
Figure 1

Typical RCA from C\&DW: a) common RCA particle and b) other materials included in RCA

a) Common RCA particle

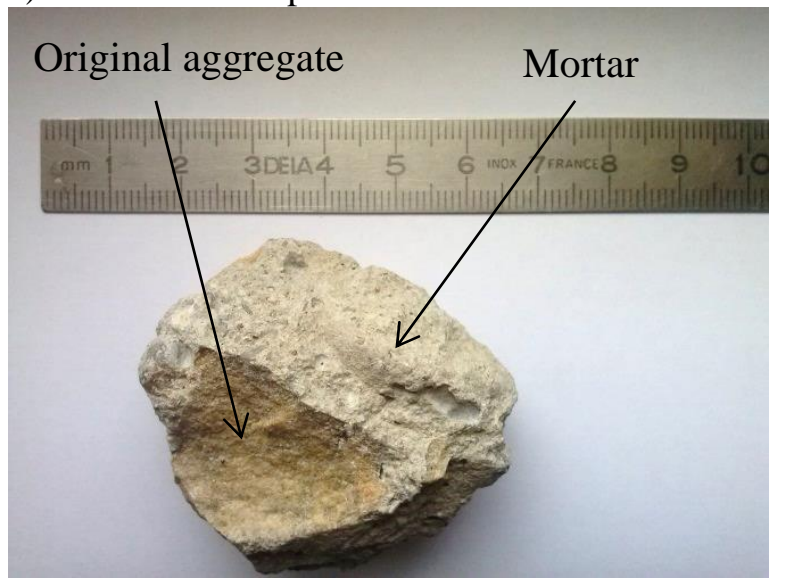

b) Other materials included in RCA

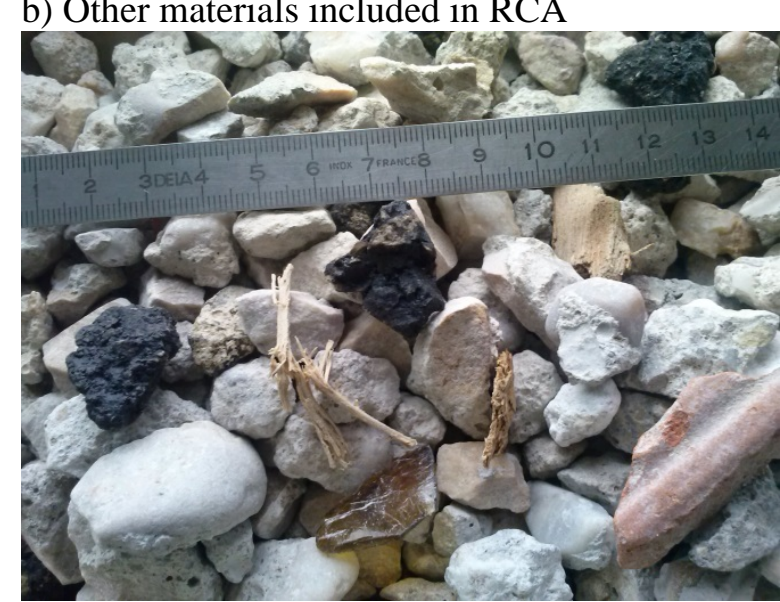


Figure 2

Optimum asphalt content of HMA using RCA

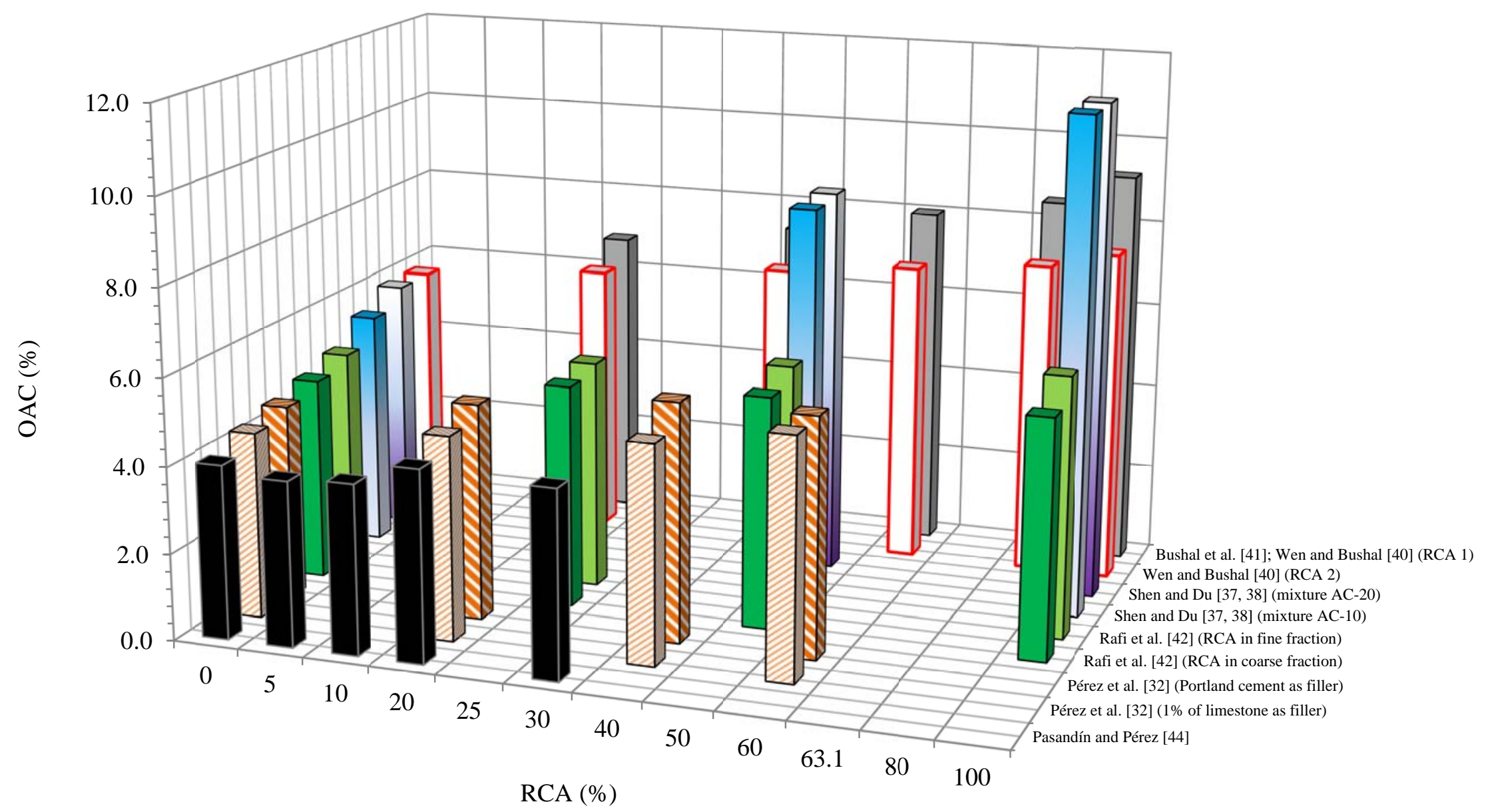


Figure 3

Bitumen absorption of HMA using RCA

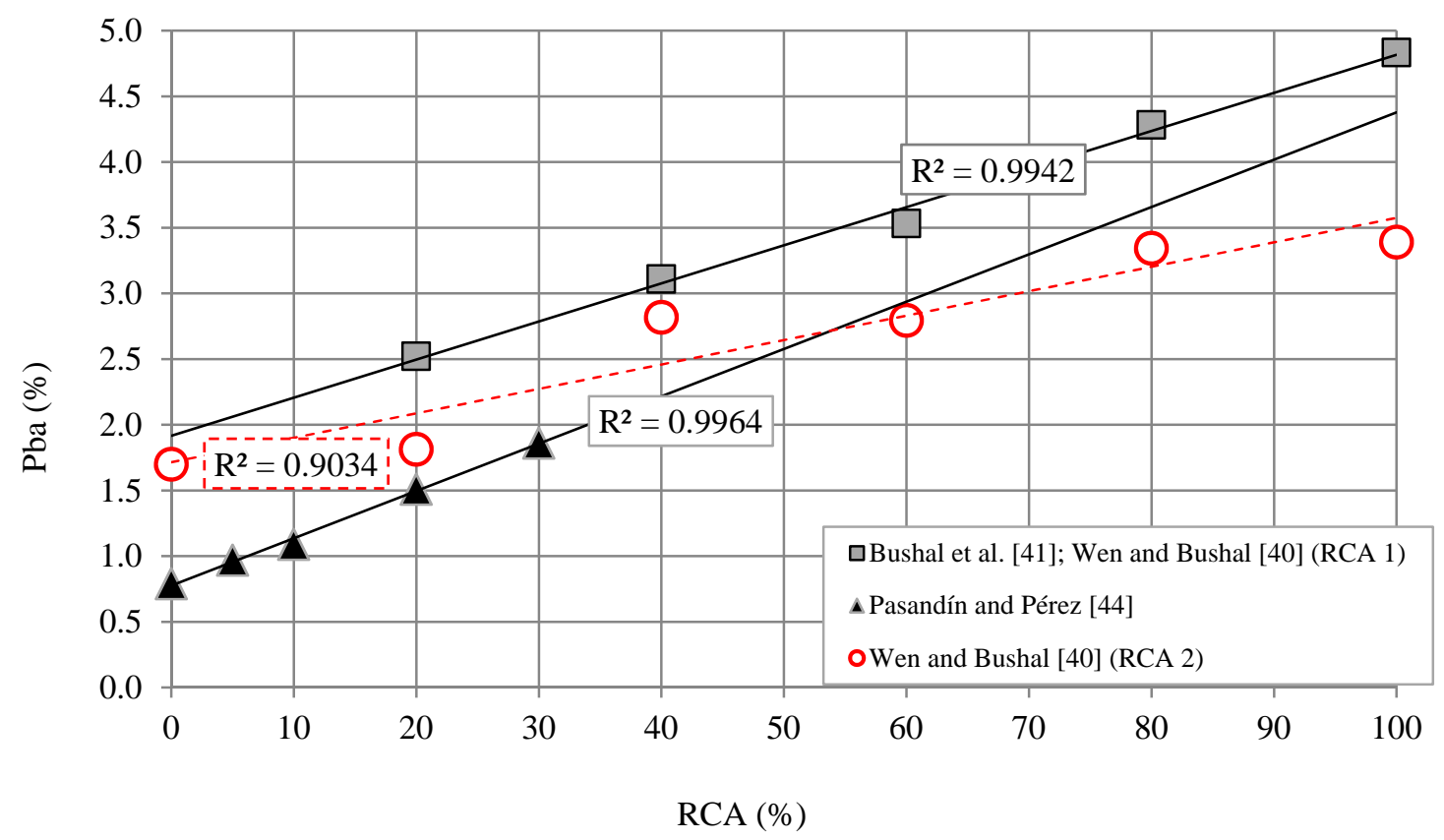


Figure 4

Volumetric properties of HMA using RCA: a) Air voids (Va), b) Voids in mineral aggregate (VMA) and c) Voids filled with asphalt (VFA)

a) Air voids (Va)

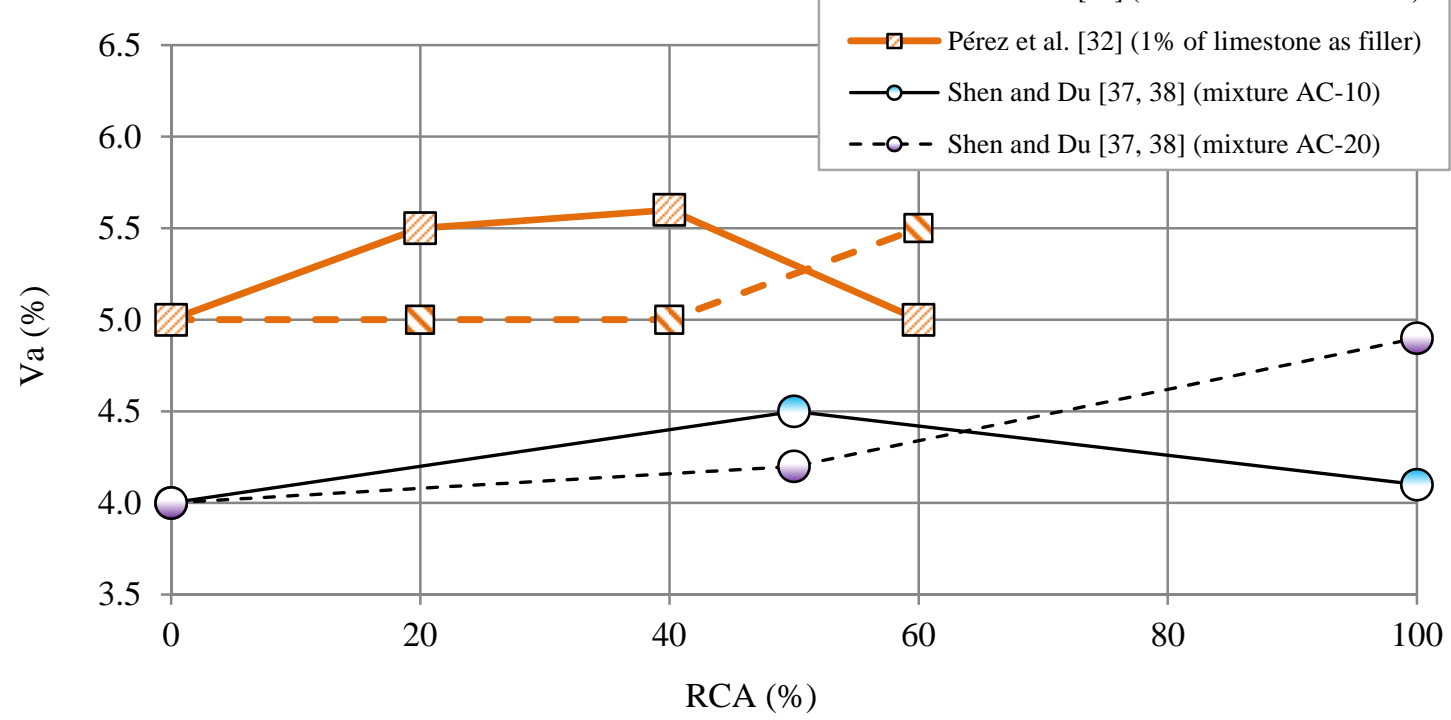

b) Voids in mineral aggregate (VMA)

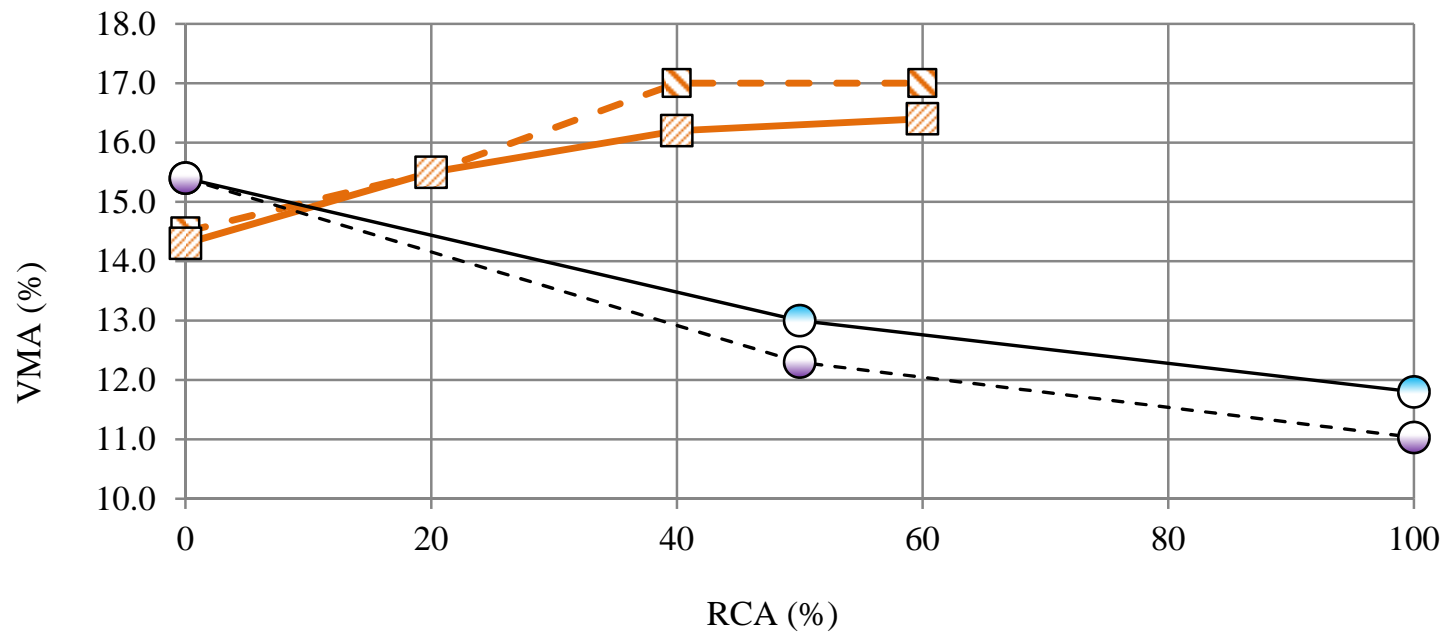

c) Voids filled with asphalt (VFA)

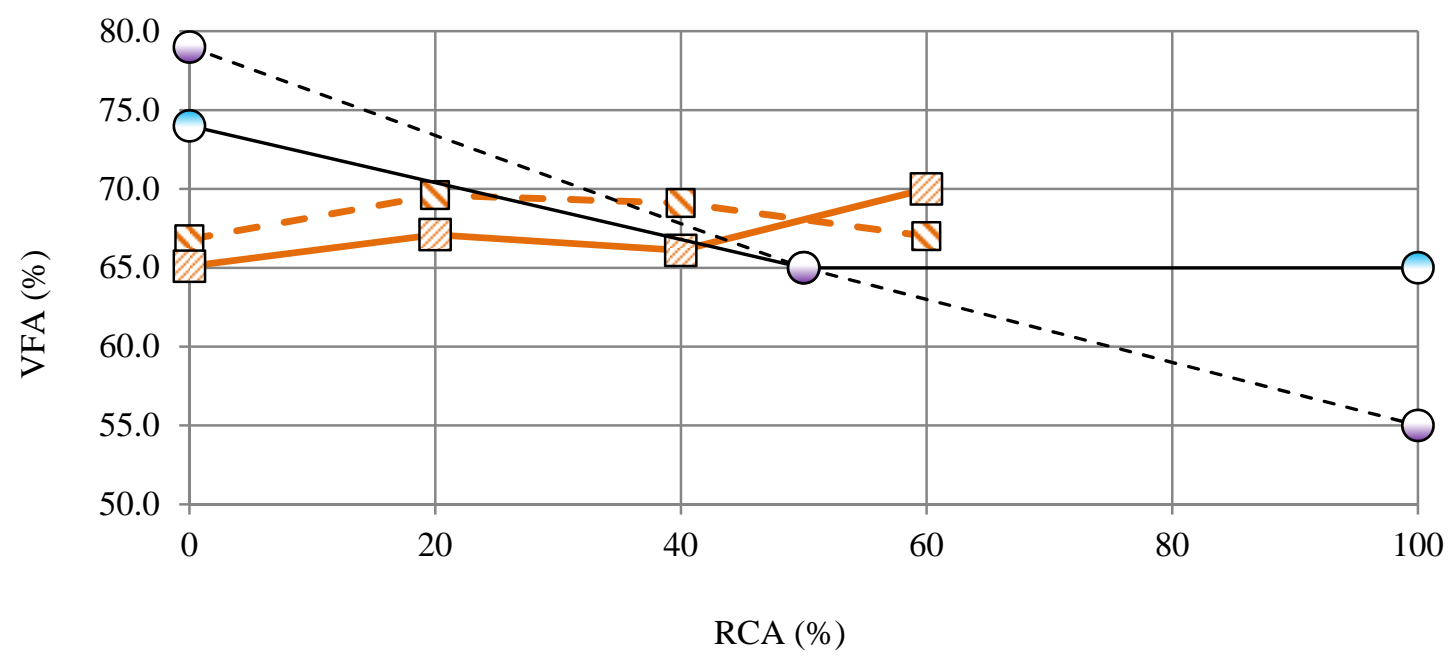


Figure 5

Marshall stability of HMA with RCA

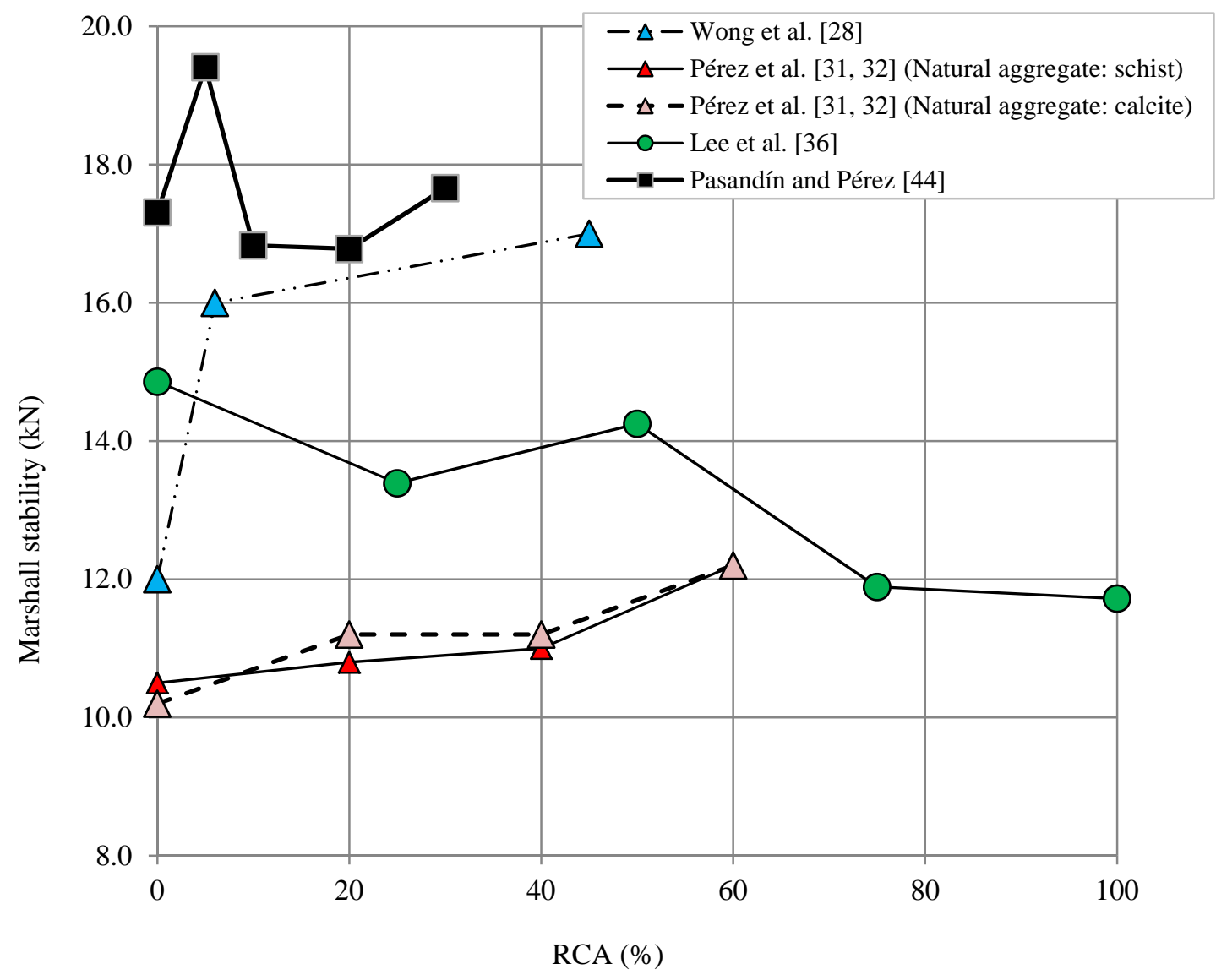


Figure 6

Resilient modulus at $25^{\circ} \mathrm{C}$ according to Arabani and Azarhoosh [49] and Arabani et al. [50]

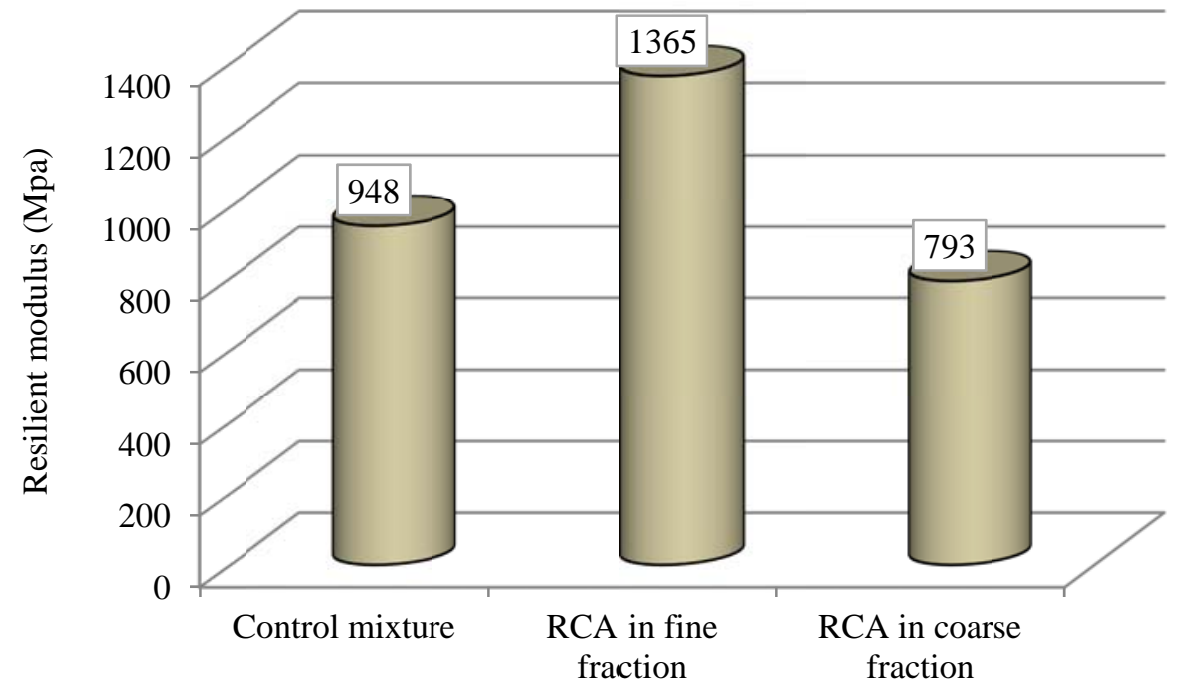


Table 1

The average composition of C\&DW

\begin{tabular}{|c|c|c|c|c|c|c|c|c|c|}
\hline Country, state or city & $\begin{array}{c}\text { Netherlands } \\
{[16]}\end{array}$ & $\begin{array}{c}\text { Denmark } \\
\text { [16] }\end{array}$ & Estonia [16] & Spain [16] & $\underset{[16]}{\text { Germany }}$ & $\begin{array}{c}\text { Ottawa } \\
\text { (CCanada) } \\
{[17]}\end{array}$ & $\begin{array}{l}\text { California } \\
\text { (USA) [18] }\end{array}$ & $\begin{array}{l}\text { Shanghai } \\
\text { (China) [19] }\end{array}$ & Taiwan [14] \\
\hline Year & 2001 & 2003 & 2006 & 2005 & 2007 & 2007 & 2008 & 2014 & 2002 \\
\hline Concrete & $40 \%$ & $32 \%$ & & $12 \%$ & & $9 \%$ & $4.1 \%$ & $22.6-42.9 \%$ & $51.7 \%$ \\
\hline Masonry & $25 \%$ & $8 \%$ & $17 \%$ & $54 \%$ & $70 \%$ & $3 \%$ & & $38.3-63.8 \%$ & \\
\hline $\begin{array}{l}\text { Asphalt (pavement and } \\
\text { rofing }\end{array}$ & $26 \%$ & $24 \%$ & $9 \%$ & $5 \%$ & $27 \%$ & $17 \%$ & $10.7 \%$ & $0 \%$ & - \\
\hline Wood & $2 \%$ & - & - & $4 \%$ & - & $26 \%$ & $49.8 \%$ & $8.4-11.2 \%$ & $10.9 \%$ \\
\hline Metal & $1 \%$ & & $40 \%$ & $3 \%$ & & $9 \%$ & & $3.1-6.5 \%$ & $5.5 \%$ \\
\hline Gypsum & & & & $0.2 \%$ & $0.4 \%$ & & $5.5 \%$ & $1.1 \%-2.1 \%$ & \\
\hline Plastic & & - & & $2 \%$ & & & & $0 \%$ & $2.4 \%$ \\
\hline Other & $6 \%$ & $36 \%$ & $34 \%$ & $19.8 \%$ & $2.6 \%$ & $36 \%$ & $29.9 \%$ & $0 \%$ & $29.5 \%$ \\
\hline
\end{tabular}

“-“: no available data 
Table 2

HMA with RCA. Summary of water resistance results

\begin{tabular}{|c|c|c|c|c|c|c|}
\hline Author & Parameter & Standard ( & RCA \% & Result & Requirement by author & Conclusions \\
\hline Shen and Du [38] & $\begin{array}{l}\text { Index of retained strength } \\
\text { (RSI) }\end{array}$ & MTC (Taiwan) & $\begin{array}{c}0(\mathrm{AC}-10) \\
50(\mathrm{AC}-10) \\
100(\mathrm{AC}-10) \\
0(\mathrm{AC}-20) \\
50(\mathrm{AC}-20) \\
100(\mathrm{AC}-20)\end{array}$ & $\begin{array}{l}92.09 \% \\
89.20 \% \\
87.71 \% \\
93.60 \% \\
91.89 \% \\
89.54 \%\end{array}$ & $>75 \%$ & $\begin{array}{l}\text { Mixtures satisfy requirements for } \\
\text { the stripping tests }\end{array}$ \\
\hline Aljassar et al. [52] & $\begin{array}{l}\text { Index of retained strength in } \\
\text { the inmersion compresion }\end{array}$ & MPW (Kuwait) & Do not indicate & $92.00 \%$ & $>70 \%$ & $\begin{array}{l}\text { Mixtures satisfy local } \\
\text { specifications }\end{array}$ \\
\hline Paranavithana et al. [29] & $\begin{array}{l}\text { Percentage of stripping } \\
\text { Wet/dry strength variation }\end{array}$ & $\begin{array}{l}\text { AS } 2758 \\
\text { (Australia) }\end{array}$ & $\begin{array}{l}\text { RCA sample } \\
\text { Crushed basalt aggregates sample } \\
\text { RCA sample } \\
\text { Crushed sasastate sagregates sample }\end{array}$ & $\begin{array}{l}12 \% \\
1 \% \\
34 \% \\
10 \%\end{array}$ & $\begin{array}{l}<10 \% \\
<35 \%\end{array}$ & $\begin{array}{l}\text { Stripping potential of RCA is } \\
\text { significantly higher }\end{array}$ \\
\hline Pérez et al. [30] & Retained Ratio (RR) & $\begin{array}{l}\text { NLT-161 and } \\
\text { NLT-162 (Spain) }\end{array}$ & $\begin{array}{c}0(\mathrm{~S}-20) \\
50(\mathrm{~S}-20) \\
0(\mathrm{G}-20) \\
50 \mathrm{G}-20) \\
\end{array}$ & $\begin{array}{l}76.99 \% \\
63.72 \% \\
79.34 \% \\
50.26 \%\end{array}$ & $>75 \%$ & $\begin{array}{l}\text { Mixtures made with } 50 \% \text { RCA do do } \\
\text { not exhibited satisfactory water } \\
\text { resistance }\end{array}$ \\
\hline Mills-Beale and You [45] & Tensile Strength Ratio & $\begin{array}{c}\text { ASTM } \\
\text { D4867/D4867-M04 } \\
\text { (United States) }\end{array}$ & $\begin{array}{l}25 \\
35 \\
50 \\
75 \\
\end{array}$ & $\begin{array}{l}>75 \% \\
>55 \% \\
>75 \% \\
<75 \% \\
\end{array}$ & $>75 \%$ & $\begin{array}{l}\text { As RCA percentage increases, the } \\
\text { moisture susceptibility of HMA } \\
\text { also increases }\end{array}$ \\
\hline Cho et al. [39] & Indirect tensile strength ratio & $\begin{array}{l}\text { ASTM D4867 and } \\
\text { KSF2398 (Korea) }\end{array}$ & $\begin{array}{l}0 \\
\text { RCA coarse fraction }(>4.75 \mathrm{~mm}) \\
\text { RCA fine fraction }(<4.75 \mathrm{~mm}) \\
100\end{array}$ & $\begin{array}{l}>0.7 \\
>0.7 \\
>0.7 \\
>0.7\end{array}$ & $>0.7$ & 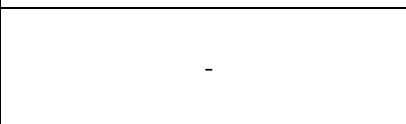 \\
\hline Wen and Bushal [40] & Tensile Strength Ratio (TSR) & $\begin{array}{l}\text { WSDOT T718 } \\
\text { (USA) }\end{array}$ & $\begin{array}{c}0 \% \text { (RCA 1) } \\
20 \% \text { (RCA 1) } \\
40 \% \text { (RCA 1) } \\
60 \% \text { (RCA 1) } \\
80 \% \text { (RCA 1) } \\
100 \% \text { (RCA } 1) \\
0 \% \text { (RCA 2) } \\
20 \% \text { (RCA 2) } \\
40 \% \text { (RCA 2) } \\
60 \% \text { (RCA 2) } \\
80 \% \text { (CA 2) } \\
100 \% \text { (RCA 2) } \\
\end{array}$ & $\begin{array}{l}88 \% \\
87 \% \\
82 \% \\
80 \% \\
77 \% \\
76 \% \\
88 \% \\
84 \% \\
82 \% \\
81 \% \\
81 \% \\
80 \% \\
\end{array}$ & $>80 \%$ & $\begin{array}{l}\text { The addition of RCA increases the } \\
\text { HMA moisture susceptibility. The } \\
\text { authors stated that increased } \\
\text { asphalt content and/or crushing of } \\
\text { RCA could explain this behaviour. }\end{array}$ \\
\hline Chen et al. [54] & Tensile Strength Ratio (TSR) & $\begin{array}{l}\text { AASHTO T-283 } \\
\text { (China) }\end{array}$ & $\begin{array}{c}0 \% \\
4 \% \text { (as filler) }\end{array}$ & $\begin{array}{l}86.30 \% \text { ( } 1 \text { cycle) } \\
75.31 \% \text { ( } 2 \text { cycles }) \\
71.30 \% \text { (3ycles) } \\
90.04 \% \text { ( } 1 \text { cycle) } \\
80.41 \% \text { ( } \text { cycles }) \\
74.50 \% \text { ( } 3 \text { cycles })\end{array}$ & Not indicated & $\begin{array}{l}\text { The use of recycled filler can } \\
\text { improve the water sensitivity of } \\
\text { the mixture }\end{array}$ \\
\hline Pérez et al. [33] & Tensile Strength Ratio (TSR) & $\begin{array}{l}\text { EN-1267-12 } \\
\text { (Spain) }\end{array}$ & 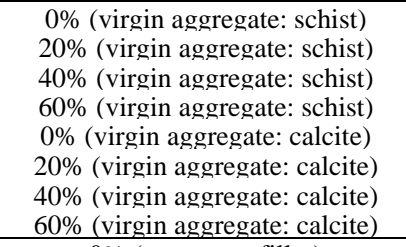 & $\begin{array}{l}88 \% \\
70 \% \\
65 \% \\
60 \% \\
96 \% \\
86 \% \\
62 \% \\
52 \% \\
\end{array}$ & $>80 \%$ & $\begin{array}{l}\text { An increase in the RCA percentage } \\
\text { was found to decrease the TSR. } \\
\text { Explained by the poor adhesion of } \\
\text { the RCA }\end{array}$ \\
\hline Pérez et al. [32] & $\begin{array}{l}\text { Retained strength ratio (RSR) } \\
\text { in immersion-compression test }\end{array}$ & NLT-162 (Spain) & 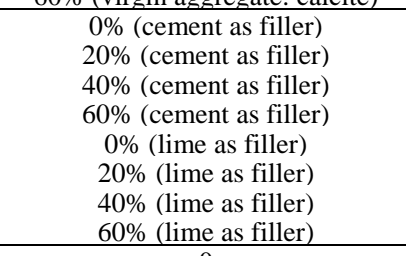 & $\begin{array}{l}85 \% \\
55 \% \% \\
554 \% \\
63 \% \% \\
69 \% \% \\
79 \% \% \\
55 \% \% \\
53 \%\end{array}$ & $>75 \%$ & $\begin{array}{l}\text { HMA with RCA present poor } \\
\text { stripping behaviour }\end{array}$ \\
\hline Zhu et al. [51] & $\begin{array}{l}\text { Residual Marshall Stability } \\
\text { (RMS) }\end{array}$ & $\begin{array}{l}\text { JTJ 052-2000 } \\
\text { (China) }\end{array}$ & $\begin{array}{c}0 \\
63.1 \\
100 \\
0\end{array}$ & $\begin{array}{l}>80 \% \\
>80 \% \\
>80 \% \\
>75 \%\end{array}$ & $\begin{array}{l}>80 \% \text { (after } 1 \text { cycle of } \\
\text { water immersion) }\end{array}$ & $\begin{array}{l}\text { The use of RCA produces HMA } \\
\text { with poor moisture resistance }\end{array}$ \\
\hline & Tensile Strength Ratio (TSR) & & $\begin{array}{l}63.1 \\
100\end{array}$ & $\begin{array}{l}>75 \% \\
>75 \%\end{array}$ & $\begin{array}{l}>75 \% \text { (after 1 cycle of water } \\
\text { freeze-thaw) }\end{array}$ & \\
\hline Wu et al. [48] & $\begin{array}{l}\text { Residual Stability ratio (MS0) } \\
\text { Tensile Strength Ratio (TSR) }\end{array}$ & RIOH (China) & $\begin{array}{c}0 \% \\
\text { RCA coarse fraction }(>4.75 \mathrm{~mm}) \\
\text { RCA fine fraction }(<4.75 \mathrm{~mm}) \\
0 \% \\
\text { RCA coarse fraction }(>4.75 \mathrm{~mm}) \\
\text { RCA fine fraction }(<4.75 \mathrm{~mm})\end{array}$ & $\begin{array}{l}>80 \% \\
>80 \% \\
>80 \% \\
>80 \% \\
>80 \% \\
>80 \%\end{array}$ & $>80 \%$ & $\begin{array}{l}\text { Mixtures satisfy technical } \\
\text { requirements, but the porous and } \\
\text { rougher RCA surface lead to } \\
\text { mixtures with lower water stability }\end{array}$ \\
\hline
\end{tabular}


Table 3

HMA involving treated RCA. Summary of results

\begin{tabular}{|c|c|c|c|c|c|c|c|c|c|}
\hline Author & Treatment applied to the RCA & Aim & $\begin{array}{l}\text { Marshall stability } \\
\text { and flow }\end{array}$ & $\begin{array}{c}\text { Moisture damage } \\
\text { resistance }\end{array}$ & Stiffness & $\begin{array}{c}\text { Resistance to the } \\
\text { permanent deformation }\end{array}$ & Fatigue life & $\begin{array}{c}\text { Low temperature } \\
\text { performance }\end{array}$ & Cost \\
\hline Wong et al. [28] & 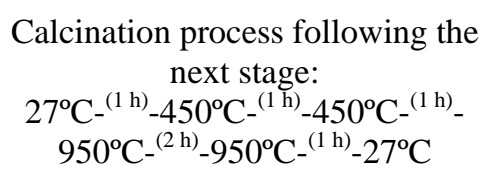 & $\begin{array}{l}\text { Transform calcium } \\
\text { carbonate in RCA into } \\
\text { lime }\end{array}$ & $\begin{array}{l}\text { Comply with } \\
\text { national } \\
\text { specifications }\end{array}$ & Not analysed & $\begin{array}{l}\text { Resilient modulus is } \\
\text { slightly lower using the } \\
\text { treated RCA than using } \\
\text { untreated RCA }\end{array}$ & $\begin{array}{l}\text { Improved using treated } \\
\text { RCA than using untreated } \\
\text { RCA }\end{array}$ & Not analysed & Not analysed & Not analysed \\
\hline Lee et al. [36] & $\begin{array}{l}\text { Precoat RCA with a slag cement } \\
\text { paste (optimum thickness: } 0.25 \\
\text { mm) }\end{array}$ & $\begin{array}{l}\text { Reinforce RCA in its } \\
\text { ability to resist crushing } \\
\text { and friction }\end{array}$ & $\begin{array}{l}\text { Comply with } \\
\text { national } \\
\text { specifications }\end{array}$ & $\begin{array}{l}\text { Mixtures comply with } \\
\text { national specifications, } \\
\text { but water resistance } \\
\text { decreases as the treated } \\
\text { RCA percentage } \\
\text { increases because of the } \\
\text { high asphalt absorption } \\
\text { of the treated RCA }\end{array}$ & $\begin{array}{l}\text { Resilient modulus } \\
\text { increases as the treated } \\
\text { RCA percentage } \\
\text { increases }\end{array}$ & $\begin{array}{l}\text { Mixtures comply with } \\
\text { national specifications. } \\
\text { Moreover, the rutting } \\
\text { potential decreases as the } \\
\text { treated RCA percentage } \\
\text { increases, because of the } \\
\text { stronger interlocking of } \\
\text { the treated RCA }\end{array}$ & Not analysed & Not analysed & Not analysed \\
\hline Zhu et al. [51] & $\begin{array}{l}\text { Precoat the RCA with a patented } \\
\text { liquid silicone resin: immerse } \\
\text { RCA into the resin for } 1 \text { hour and } \\
\text { then heat it in an oven for } 24 \\
\text { hours at } 60^{\circ} \mathrm{C} \text { to solidify the resin }\end{array}$ & $\begin{array}{c}\text { Reduce RCA absorption } \\
\text { and strengthen the RCA } \\
\text { by blocking the RCA } \\
\text { pores }\end{array}$ & $\begin{array}{l}\text { Comply with } \\
\text { national } \\
\text { specifications }\end{array}$ & $\begin{array}{l}\text { Mixtures made using } \\
\text { treated RCA displayed } \\
\text { higher water resistance } \\
\text { than mixtures made } \\
\text { using untreated RCA }\end{array}$ & $\begin{array}{c}\text { The use of RCA } \\
\text { degrades the low } \\
\text { temperature flexibility } \\
\text { of HMA. The treatment } \\
\text { applied to RCA } \\
\text { improves the flexibility. }\end{array}$ & $\begin{array}{l}\text { Mixtures made with } \\
\text { treated RCA displayed } \\
\text { greater rutting potential } \\
\text { than mixtures made with } \\
\text { untreated RCA. } \\
\text { Nevertheless, treated and } \\
\text { untreated RCA lead to } \\
\text { mixtures with better } \\
\text { resistance to the } \\
\text { permanent deformation } \\
\text { than mixtures produced } \\
\text { with only natural } \\
\text { aggregates }\end{array}$ & Not analysed & Not analysed & Not analysed \\
\hline $\begin{array}{c}\text { Pasandín and Pérez } \\
\text { [44] }\end{array}$ & $\begin{array}{l}\text { Keep the loose mixture for } 4 \\
\text { hours in an oven at } 170^{\circ} \mathrm{C} \text { after } \\
\text { mixing and before compacting }\end{array}$ & $\begin{array}{l}\text { This treatment produces a } \\
\text { higher bitumen } \\
\text { absorption, which } \\
\text { improves RCA attached } \\
\text { mortar resistance and } \\
\text { obstructs the RCA pores, } \\
\text { preventing the entry of } \\
\text { water }\end{array}$ & $\begin{array}{l}\text { High Marshall } \\
\text { stabilities of } \\
\text { mixtures produced } \\
\text { with the treatment }\end{array}$ & $\begin{array}{l}\text { Mixtures produced with } \\
\text { RCA that have been } \\
\text { cured in an oven for } 4 \\
\text { hours comply with } \\
\text { Spanish moisture } \\
\text { damage specifications. } \\
\text { This treatment improves } \\
\text { the moisture damage } \\
\text { resistance of the } \\
\text { mixtures }\end{array}$ & $\begin{array}{l}\text { Higher stiffness of } \\
\text { mixtures are produced } \\
\text { with this treatment }\end{array}$ & $\begin{array}{l}\text { Up to } 30 \% \text { of RCA, the } \\
\text { mixtures exhibited good } \\
\text { resistance to permanent } \\
\text { deformation. Nevertheless, } \\
\text { higher RCA percentages } \\
\text { could lead to mixtures } \\
\text { with excessive rutting } \\
\text { potential. }\end{array}$ & $\begin{array}{l}\text { Similar to } \\
\text { conventional mixtures } \\
\text { up to } 20 \% \text { of RCA. } \\
30 \% \text { of RCA shows a } \\
\text { fatigue life that is } \\
\text { slightly slower than } \\
\text { conventional } \\
\text { mixtures. }\end{array}$ & $\begin{array}{l}\text { Such mixtures should } \\
\text { not be used in cold } \\
\text { regions because of the } \\
\text { high resilient modulus } \\
\text { at } 0^{\circ} \mathrm{C}\end{array}$ & Not analysed \\
\hline $\begin{array}{c}\text { Pasandín and Pérez } \\
\text { [56] }\end{array}$ & $\begin{array}{l}\text { Coat the RCA with a } 5 \% \text { of } \\
\text { bitumen emulsion prior to the } \\
\text { mixing process }\end{array}$ & $\begin{array}{l}\text { Obstructs the RCA pores, } \\
\text { preventing the entry of } \\
\text { water and thus, improves } \\
\text { the moisture damage } \\
\text { resistance. In addition, } \\
\text { the bitumen emulsion } \\
\text { achieves a better } \\
\text { chemical affinity with the } \\
\text { bitumen. }\end{array}$ & Not analysed & $\begin{array}{l}\text { Mixtures made with } \\
\text { RCA coated with } \\
\text { bitumen emulsion } \\
\text { comply with Spanish } \\
\text { moisture damage } \\
\text { specifications. This } \\
\text { treatment improves the } \\
\text { moisture damage } \\
\text { resistance of the } \\
\text { mixtures }\end{array}$ & $\begin{array}{l}\text { Similar to conventional } \\
\text { mixtures }\end{array}$ & $\begin{array}{c}\text { Similar to conventional } \\
\text { mixtures }\end{array}$ & $\begin{array}{c}\text { Similar to } \\
\text { conventional mixtures }\end{array}$ & Not analysed & Not analysed \\
\hline
\end{tabular}

